\title{
Some ecological studies on the impact of magnetic field on the tap water
}

\author{
Zeinab Z. K. Khater ${ }^{1}$ and Mona H. Ibraheim ${ }^{2}$
}

1- Department of Zoology, Faculty of Science, Zagazig University, Egypt

2- Department of Physics, Faculty of Science, Zagazig University, Egypt

E-mail: z_sci.egy@zu.edu.eg, mhmekky@ zu.edu.eg

\section{ABSTRACT}

The aim of the present study is to know the effects of the magnetic field on water purification. Samples were collected from tap water of Faculty of Science, Zagazig University, Zagazig, Egypt, and then treated using the magnetic field. Water was exposed to a weak static magnetic field (MF) generated from a stack of magnets $(B=18 \mathrm{G})$. After this treatment, the physico-chemical parameters of water were measured, as well as the heavy metal concentrations. The results showed that the magnetic field has a very great effect on physico-chemical parameters of the water, as it decreases its concentrations in water samples. The magnetic field with an intensity of $18 \mathrm{G}$ has a very great effect on water purification, but it is not recommended to use it in treating water pollution without sufficient studies on its safety on the living organisms live in and drinking it.

Keywords: Water pollution treatment, magnetic field, magnetized water, heavy metals, tap water.

\section{INTRODUCTION}

Phenomenon of water treatment with an applied magnetic field has been known for many years and has been reported as being effective in numerous instances (Balcavage et al., 1996). From scientific literature, it is known that biological systems give different bio-responses to extremely low-frequency magnetic field exposures at gaseous matters in addition to living organisms. Sohaili et al. (2004) observed that magnetic technology is a promising treatment process that can enhance the separation of suspended particles from the sewage. Tai et al. (2008) concluded that on subjecting water to the magnetic field, it leads to modification of its properties, as it becomes more energetic and able to flow which can be considered as a birth of new science called Magneto biology. Magnetic wastewater treatment has been introduced to the chemical industry to remove heavy metals (Tsouris et al., 2001). It was found that magnetized water helps in dissolving minerals and acids by a higher rate than unmagnetized water, in addition to dissolving oxygen and increasing the speed of chemical reactions (Moon and Chung, 2000). Florenstano et al. (1996) observed that only the mineral content i.e. TDS (Total Dissolved Solids) that builds up after water is contacted with magnetic fields. Among different physical and chemical methods of water and wastewater treatments; magnetic methods attract a special attention due to their ecological purity, safety, simplicity and less operating costs. Alteration of physical and chemical properties of water-dispersed systems in the mode of magnetic treatment implies a certain influence of magnetic field on the structure of water and aqueous solutions. Previous researches made by several scientific societies has discovered that magnetic field can improve technological characteristics of the water, i.e. better salt solubility, kinetic changes in salt crystallization and accelerated colloidal coagulation. The magnetic field is known to create the asymmetry of hydrated shells due to its effect on water molecules situated around the charged particles (colloid). Exposure to magnetic field would lead to a higher electrokinetic 
movement among the colloid. This will definitely increase the probability of attracting particles to cloak with one another. The theory of magnetic field impact on technological processes for water treatment falls into two main categories; crystallization at magnetic water preparation and impurity coagulation in water systems (Fadil et al., 2001).

Due to the limited information and data concerning the magnetic field effects on water, the aim of the present study is to investigate the impact of magnetic field on some physico-chemical properties of water, and its possible using it in the treatment of waste water.

\section{MATERIALS AND METHODS}

\section{Sampling area:}

Tap water samples were collected from Faculty of Science, Zagazig University, Egypt.

\section{Analytical procedures:}

Water samples (twelve samples) were taken from the study site, where half of the samples were subjected to magnetic field [magnetic liquid modifier L.L.C. (Fig. 1)] and the others used as control. All samples were analyzed for water quality (chemical and physical characteristics of water). Heavy metals; zinc ( $\mathrm{Zn}$ ), copper $(\mathrm{Cu})$, cobalt $(\mathrm{Co})$ and aluminium $(\mathrm{Al})$ were also analyzed.

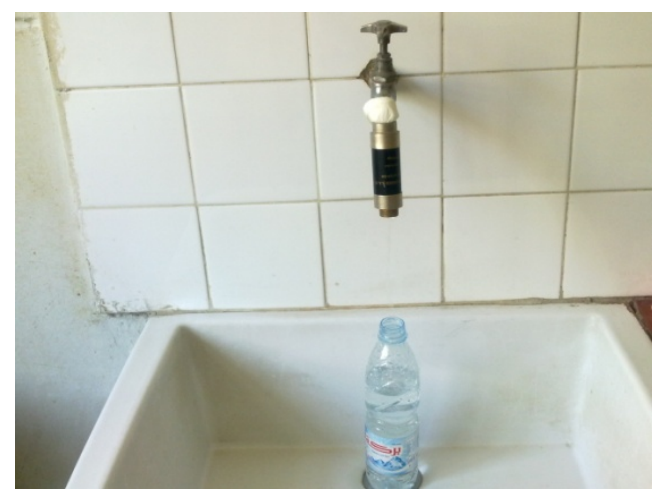

Fig. 1: The magnetic apparatus in the tap water

\section{Water examinations:}

Physico-chemical parameters of water:

Samples of water were taken, and then placed in a clean sampling glass bottle, according to Boyd (1990).

\section{Temperature:}

The water temperature was measured by a mercury thermometer of 0 to $50^{\circ} \mathrm{C}$ range.

\section{Conductivity:}

The conductivity was measured by a conductivity meter HI 98302 DIST 2. The pH value: $55)$.

It was measured by glass electrode $\mathrm{pH}$-meter (Digital Mini-pH-Meter model

Dissolved oxygen (DO) and total dissolved solids (TDS): 
Dissolved oxygen and total dissolved solids have been measured according to Ibraheim and Khater (2013).

\section{Carbon dioxide $\left(\mathrm{CO}_{2}\right)$ and alkalinity:}

It has been determined according to Gupta (2000).

\section{Chlorinity:}

Salinity:

Chlorinity has been measured by a digital chlorimeter (model HI 93711).

Salinity has been measured by a digital salinometer (model Atago Hand Refractometer).

\section{Heavy metals in water:}

Twelve water samples were collected from a tap water for heavy metals analysis; half of which were exposed to the magnetic field, and the others as control, put in cleaned bottles and stored until analysis was carried out. Heavy metal concentrations were determined by atomic absorption spectrophotometer (Perkin Elmer, 2280). The water samples were prepared and analyzed in sequential for zinc, copper, cobalt and aluminum according to APHA (1985).

\section{Statistical analysis:}

Bishop (1980) and McCreadie et al. (2006) found that the statistical analysis is performed using the analysis of Independent t-test to determine the differences between the treatments mean at the significant level of 0.05 . Standard deviations were also estimated. All statistics were run on the computer using SPSS program. All graphics and tables were made using Origin 8 and Microsoft word (2007). The methods used for analysis of the present results were done according to them.

\section{RESULTS AND DISCUSSION}

\section{Water analysis:}

\section{Physico-chemical parameters of water:}

Comparing the average means of the same physico chemical parameters of water samples in the different pre and post- exposed levels, the data recorded in the Table (1) and Figs. (2-10) determined remarkable variations in it.

Table 1: The physico-chemical parameters (mean $\pm \mathrm{SD}$ ) of water samples before and after exposure to the magnetic field.

\begin{tabular}{|l|l|l|}
\hline \multicolumn{1}{|c|}{ Magnetic field } & Pre-exposure & post-exposure \\
Parameters & & \\
\hline Temperature ( ${ }^{\circ}$ ) & $25 \pm 0$ & $25 \pm 0$ \\
\hline Conductivity (ppm) & $\mathbf{0 . 2 1 0} \pm \mathbf{0 a}$ & $\mathbf{0 . 2 0 0} \pm \mathbf{0 a}$ \\
\hline pH & $7.150 \pm \mathbf{0}$ & $\mathbf{7 . 0 5 0} \pm \mathbf{0}$ \\
\hline Dissolved oxygen (ppm) & $\mathbf{0 . 4 5 0} \pm \mathbf{0 . 0 7 1 a}$ & $\mathbf{0 . 1 5 0} \pm \mathbf{0 . 0 7 1 a}$ \\
\hline Carbon dioxide (ppm) & $\mathbf{1 0 . 0 5 0} \pm \mathbf{0 . 0 7 1 a}$ & $\mathbf{6 . 5 0 0} \pm \mathbf{0 . 0 7 1 a}$ \\
\hline Chlorinity (\%o) & $\mathbf{1 6 . 1 0 0} \pm \mathbf{0}$ & $\mathbf{1 6 . 1 0 0} \pm \mathbf{0}$ \\
\hline Salinity (\%o) & $\mathbf{2 9} \pm \mathbf{0}$ & $\mathbf{2 9} \pm \mathbf{0}$ \\
\hline Total dissolved solids (ppt) & $\mathbf{0 . 2 0 0} \pm \mathbf{0}$ & $\mathbf{0 . 2 0 0} \pm \mathbf{0}$ \\
\hline Akalinity (ppm) & $\mathbf{1 3 8 . 5 0} \pm \mathbf{0 . 2 1 2 a}$ & $\mathbf{1 3 1 . 5 0} \pm \mathbf{0 . 0 7 1 a}$ \\
\hline
\end{tabular}

- Data are represented as mean $\pm \mathrm{SD},(\mathrm{n}=12)$.

- Means with the same letters in the same row are significantly different $(\mathrm{p}<0.05)$, using Independent t-test. 


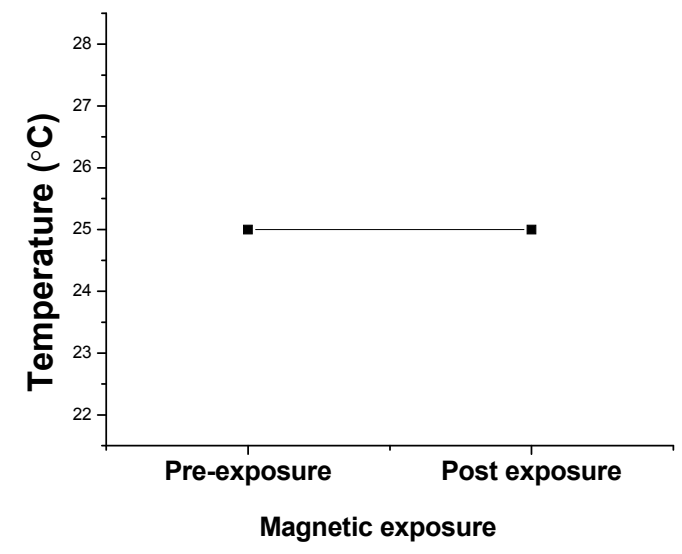

Fig. 2: The temperature (Mean $\pm \mathrm{SD}$ ) of water samples before and after the magnetic exposure.

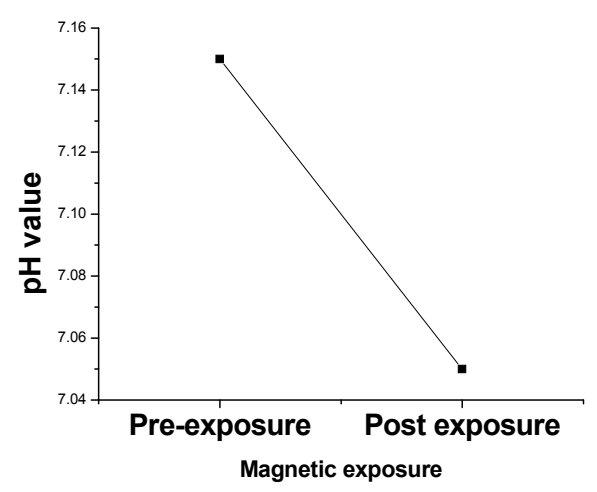

Fig. 4: The $\mathrm{pH}$-value (Mean $\pm \mathrm{SD}$ ) of water samples before and after the magnetic exposure.

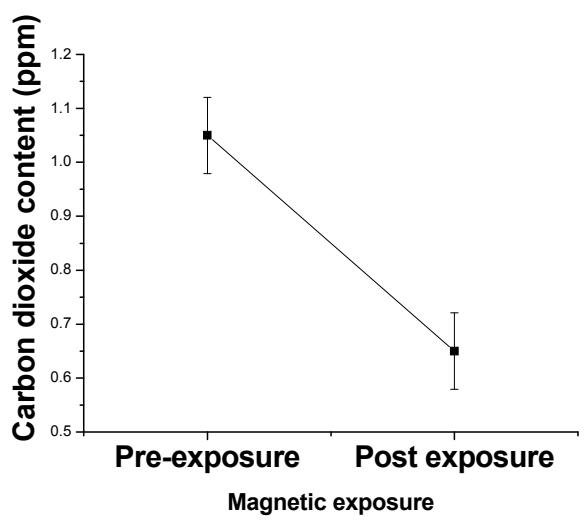

Fig. 6: The carbon dioxide content $($ Mean $\pm \mathrm{SD})$ ater samples before and after the magnetic exposure.

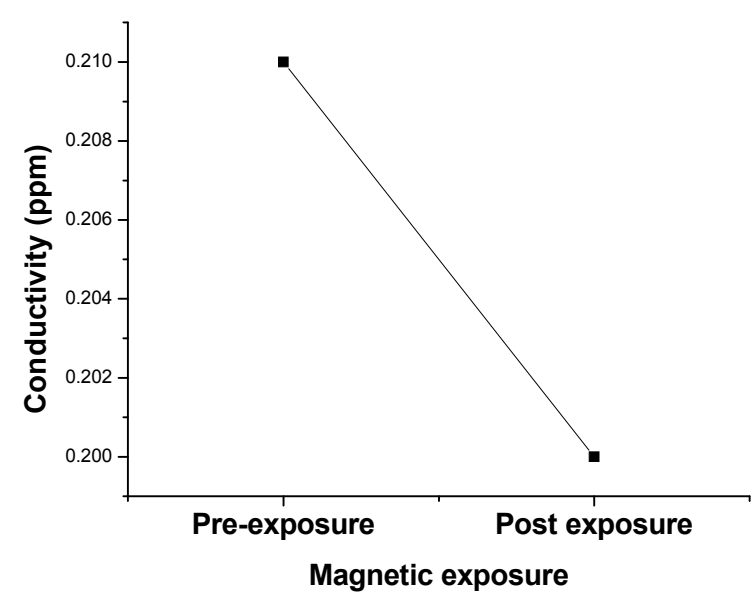

Fig. 3: The conductivity (Mean \pm SD) of water samples before and after the magnetic exposure.

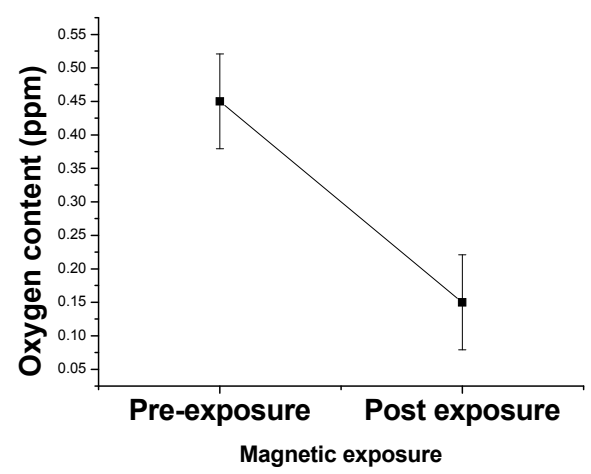

Fig. 5: The oxygen content (Mean $\pm \mathrm{SD}$ ) of water samples before and after the magnetic exposure.

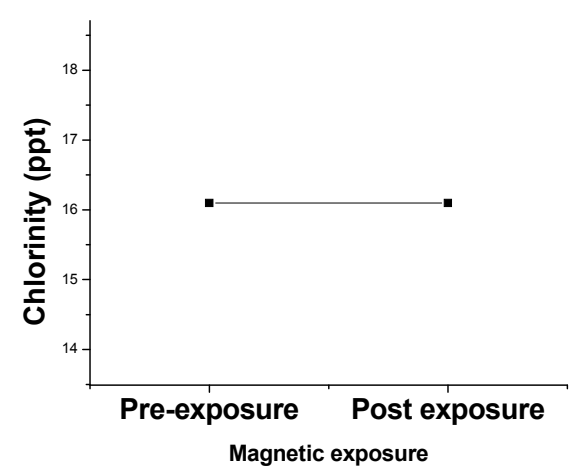

Fig. 7: The chlorinity (Mean $\pm \mathrm{SD}$ ) of water of samples before and after the magnetic exposure 


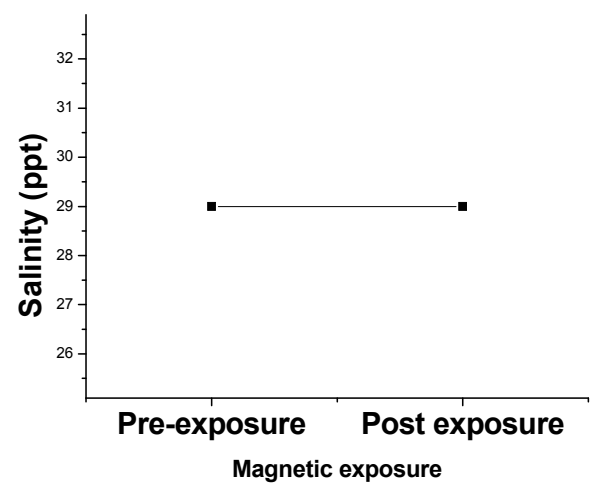

Fig. 8: The salinity (Mean $\pm \mathrm{SD}$ ) of water samples before and after the magnetic exposure.

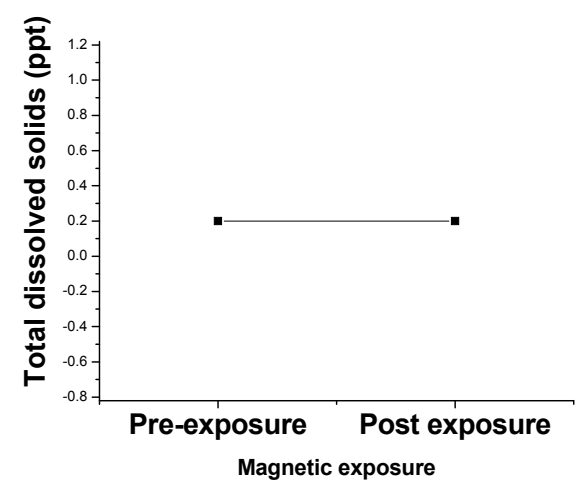

Fig. 9: The total dissolved solids (Mean \pm SD) of water samples before and after the magnetic exposure.

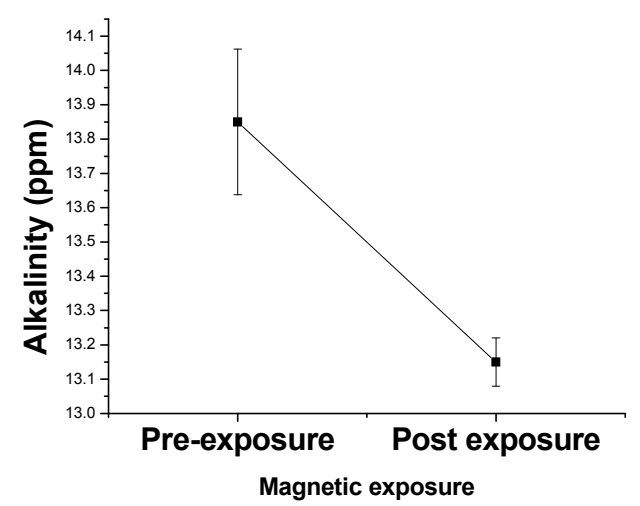

Fig. 10: The alkalinity (Mean $\pm \mathrm{SD}$ ) of water samples before and after the magnetic exposure.

\section{Heavy metals in water:}

The average concentrations of the heavy metals in the different exposure levels recorded in the Table (2) and Fig. (11). It showed remarkable variations in the heavy metal concentrations in water samples. The concentrations had the order: $\mathrm{Al}>\mathrm{Zn}>$ $\mathrm{Cu}>\mathrm{Co}$.

Table 2: The heavy metal concentrations (mean $\pm \mathrm{SD}$ ) of water samples before and after exposure to the magnetic field.

\begin{tabular}{|ll|l|l|}
\hline \multicolumn{2}{|c|}{ Magnetic field } & Pre-exposure & post-exposure \\
Parameters & & \\
\hline Zinc (Zn) & ppm & $0.047 \pm 8.485 E-4 a$ & $0.015 \pm 2.121 E-4 a$ \\
\hline Copper $(\mathrm{Cu})$ & ppm & $0.006 \pm 0.002 \mathrm{a}$ & $0.000 \mathrm{a}$ \\
\hline Cobalt (Co) & ppm & $\mathbf{0 . 0 0 5} \pm 9.899 \mathrm{E}-4 \mathrm{a}$ & $\mathbf{0 . 0 0 3} \pm \mathbf{0 . 0 0 1 a}$ \\
\hline Aluminium (Al) & ppm & $\mathbf{0 . 0 7 4} \pm 0.019 \mathrm{a}$ & $\mathbf{0 . 0 4 1} \pm \mathbf{0 . 0 1 1 a}$ \\
\hline
\end{tabular}

- Data are represented as mean $\pm \mathrm{SD},(\mathrm{n}=12)$.

- Means with the same letters in the same row are significantly different $(p<0.05)$, using Independent t-test. 


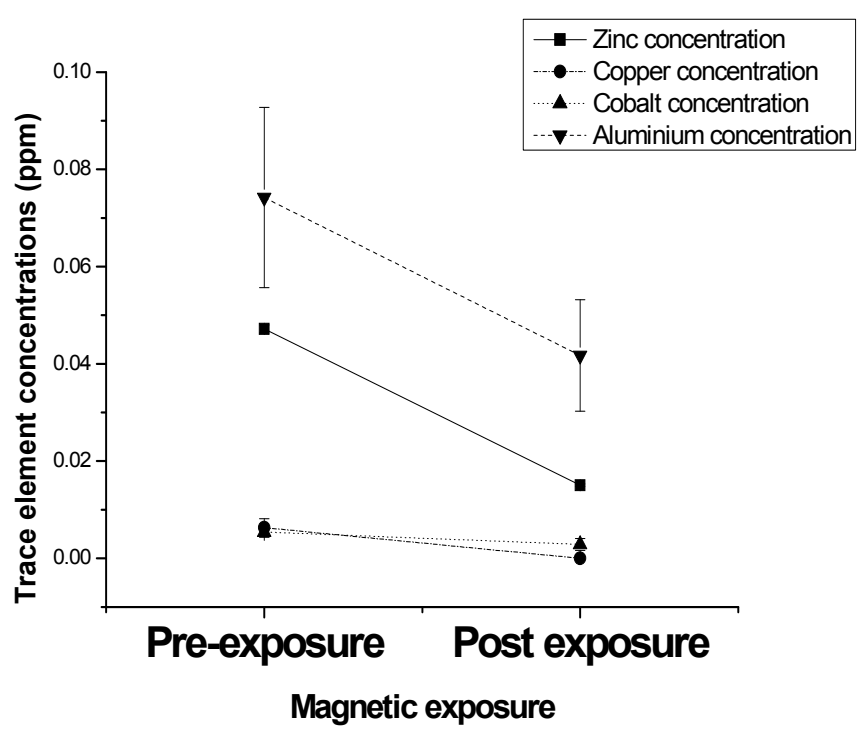

Fig. 11: The trace element concentrations (Mean \pm SD) of water samples before and after the magnetic exposure.

\section{Physico-chemical parameters:}

It is thought that modifications to the properties of solutions flowing through the magnetic field resulted from changes in the molecular structure of liquids, polarization and arrangement of particles, and finally from changes of the electric potential (Krzemieniewski et al., 2004).

This data of the present study can lead to important conclusions which may be of great importance for evaluating the benefits and hazards of the exposures to low frequency low-level magnetic field. The data of the physic-chemical parameters of water samples as given in Table (1), show that there are decreasing in the values of conductivity, $\mathrm{pH}$ value, dissolved oxygen, carbon dioxide and alkalinity for the exposed water samples relative to the unexposed one.

The present study indicated that there is no change in values of water temperature in the various examined samples due to the magnetic exposure and this range of water temperature was favorable for all living organisms according to results obtained by Owei and Ologhadien (2009); Rahim et al. (2009); Sithik et al. (2009).

In the present study, the conductivity of all the examined samples decreased and this agreed with Alkhazan and Sadddiq (2010) who found that it decreases after the magnetic exposure.

The present investigations observed that the $\mathrm{pH}$ values of all the examined samples were always on the neutral side and there was an effect of the magnetic field on it. It is disagreed with that of Alkhazan and Sadddiq (2010) who observed that the $\mathrm{pH}$ value increased with the magnetic field and agreed with Shatalov (2009) who indicated a decrease in $\mathrm{pH}$ values with magnetic exposure. The data obtained in this study indicate that the $\mathrm{pH}$ values of all the study samples lie within the favorable limits (6.2-8.3) needed for the growth and survival of living organisms and comply with results of Korai et al. (2008) and Pandey \& Tiwari (2009).

The decrease in $\mathrm{O}_{2}$ after the magnetic exposure in this investigation is agreed with that of Shatalov (2009). From the obtained data, it is clear that DO content at all examined samples lied below the limit $(>5 \mathrm{mg} / \mathrm{l})$ that satisfy the needs of successful production of the living organisms as reported by ANZECC (2000); Pandey and 
Tiwari (2009) and Sithik et al. (2009). This may be due to the type of water (tap water).

The decrease in $\mathrm{CO}_{2}$ after the magnetic exposure in the study is agreed with that of Shatalov (2009) and Alkhazan and Sadddiq (2010) and Khater and Ibraheim (2015). From the obtained data, it is clear that $\mathrm{CO}_{2}$ content at all study levels lied below the limit $(>5 \mathrm{mg} / \mathrm{l})$ that satisfy the needs of successful production of the living organisms as reported by ANZECC (2000); Ayoola and Kuton (2009) and Sithik et al. (2009).

The salinity and TDS contents did not change in the examined samples and this disagreed with $\mathrm{Ni}^{\prime}$ am et al. (2006) and Alkhazan and Sadddiq (2010), and may be related to the short period of the magnetic exposure and weak intensity of the magnetic field, although the range of salinity in the study $(<3 \mathrm{mg} / \mathrm{l})$ is suitable for survival of the living organisms and man.

The values of alkalinity decreased after the exposure to the magnetic field and this agreed with $\mathrm{Ni}^{\prime}$ am et al. (2006). The range of alkalinity $(20 \mathrm{mg} / \mathrm{l})$ in the study was not recommended, as mentioned by ANZECC (2000); Ayoola and Kuton (2009); Sithik et al. (2009).

\section{Heavy metals in water:}

The mean concentrations of $\mathrm{Zn}$ in this study were below the permissible limits (3 mg/l) recommended by WHO (2008) at all the study sites. These results are nearly similar to those obtained by İncekara (2009) and Khater (2011), whereas they are lesser than those reported by Obasohan (2007); Frankowski et al. (2009). Moreover, the mean concentrations of $\mathrm{Zn}$ decreased after the exposure to the magnetic field.

The present results showed that the mean $\mathrm{Cu}$ concentrations were under the permissible levels $(2.0 \mathrm{mg} / \mathrm{l})$ recommended by WHO (2008) at all the study samples. A comparison of the results showed that $\mathrm{Cu}$ levels were within the range of $\mathrm{Cu}$ levels recorded by Frankowski et al. (2009); Miclean et al. (2009), but higher than those observed by Akoto and Adiyiah (2007); İncekara (2009).

The mean Co concentrations in this investigation were higher than the permissible levels $(0.0014 \mathrm{mg} / \mathrm{l})$ recommended by ANZGFWQ (2000a) at all the study samples. Comparative Co levels were recorded by Abdul Ghaffar et al. (2009), El-Sayed et al. (2011) and Khater (2014). Also, as in $\mathrm{Zn}$ and $\mathrm{Cu}$, the magnetic exposure decreased the mean concentrations of Co.

The mean Al concentrations were lower than the permissible levels $(0.2 \mathrm{mg} / \mathrm{l})$ recommended by WHO (2008) at all the examined samples. The concentrations of Al in the present study were lower than those recorded by Awofolu (2006); and Abdul Ghaffar et al. (2009).

Moreover, the concentrations of all heavy metals were decreased in all water samples after the exposure to the magnetic field and this may be related to the direct effect of the magnetic field on chemical characteristics of water and attraction of macromolecules. This is agreed with those of Kholodov (1974), Alkhazan and Sadddiq (2010) and Khater and Ibraheim (2015). This decrease may be explained as the magnetic force breaks hydrogen bonds between water molecules, so the ions become separated and combine with elements and precipitate (Alkhazan and Sadddiq, 2010). In addition, Chang and Weng (2008) found that the enhanced mobility of the ions under a magnetic field causes serious damage to the hydrogen bond network in the high $\mathrm{Na}$ concentration solution. Conversely, in the low concentration solution, the structural behavior is dominated by the properties of the water molecules and hence the hydrogen bonding ability is enhanced, as the magnetic field is increased. 


\section{CONCLUSION}

The results of this study concluded that the effects of exposure of water to extremely low-frequency magnetic field depend on the magnetic field intensity, frequency and the period of exposure, and the interference of the applied magnetic field with the water used. Although the benefits of the magnetic field in treating the water pollution, it has harmful effects on kidney tissue cells of the studied rats drinking this magnetized water. So, using the magnetic field with an intensity of $18 \mathrm{G}$ is not a safe method for treating water pollution. Many studies must be done to reveal the safety of magnetic field usage before it is applied.

\section{REFERENCES}

Abdul Ghaffar, A. M.; Tabata, M.; Eto, Y.; Nishimoto, J. and Yamamoto, K. (2009). Distribution of heavy metals in water and suspended particles at different sites in Ariake Bay, Japan. EJEAFChe, 8(5): 351-366.

Akoto, O. and Adiyiah, J. (2007). Chemical analysis of drinking water from some communities in the Brong Ahafo region. Int. J. Environ. Sci. Tech., 4(2): 211214.

Alkhazan, M. M. K. and Sadddiq, A. A. N. (2010). The effect of magnetic field on the physical, chemical and microbiological properties of the lake water in Saudi Arabia. Journal of Evolutionary Biology Research, 2(1): 7-14.

American Public Health Association (APHA) (1985). Standard methods for the examination of water and wastewater. 16th ed., Washington, D. C.

ANZECC (2000). Australian and New Zealand guidelines for fresh and marine water quality. Australian and New Zealand Environmental Conservation Council \& Agriculture and Resource Management Council of Australian and New Zealand. Canberra, pp. 1-123.

Australian and New Zealand guidelines for fresh and marine water quality (ANZGFWQ) (2000). Vol. 2. Aquatic Ecosystems- Rational and background information. Chapter 8.

Awofolu, O. R. (2006). Elemental contaminants in groundwater: A study of trace metals from a residential area in the vicinity of an industrial area in Lagos, Nigeria. The Environmentalist, 26 (4): 285-293.

Ayoola, S. O. and Kuton, M. P. (2009). Seasonal variation in fish abundance and physicochemical parameters of Lagos Lagoon, Nigeria. African Journal of Environmental Science and Technology, 3(5): 149-156.

Balcavage, W. X.; Alvager, T.; Swez, J.; Goff, C. W.; Fox, M. T.; Abdullyava, S. and King, M. W. (1996). A mechanism for the action of extremely low-frequency electromagnetic fields on biological systems. Biochem. Biophys. Res. Commun., 222: 374-378.

Bishop, O. V. (1980). A practical guide for the experimental biologist. In "Statistics for Biology", Bishop, O. V. (ed.), 3rd edition, Longman group limited, 28pp.

Boyd, C. E. (1990). Water quality in ponds for aquaculture. Alabama Agriculture Experiment Station, Auburn Univ., Alabama, U. S. A.

Chang T.K. and Weng, CI. (2008). An investigation into the structure of aqueous $\mathrm{NaCl}$ electrolyte solutions under magnetic fields. Comput. Mater. Sci., 43: 1048-1055. 
El-Sayed, E. A.; El-Ayyat, M. S.; Nasr, E. and Khater, Z. Z. K. (2011). Assessment of heavy metals in water, sediment and fish tissues from Sharkia province, Egypt. Egypt. J. Aquat. Biol. \& Fish, 15 (2): 125-144.

Fadil, O.; Johan, S. and Zularisham (2001). Application of magnetic field to enhance wastewater treatment process. The $8^{\text {th }}$ Joint MMM- Intermag Conference. January 7-11. San Antonio, Texas: IEEE.

Florenstano, E.J.; Marchello, J. A. and Bhat, S, M. (1996). Magnetic water treatment in lieu of chemicals. Chemical Engineering World, 31 (10): 133 - 136.

Frankowski, M.; Sojka, M.; Ziola-Frankowska, A.; Siepak, M. and MuratBlażejewska, S. M. (2009). Distribution of heavy metals in the Mala Welna River system (western Poland). International Journal of Oceanography and Hydrobiology, XXXVIII (2): 51-61.

Gupta, P. K. (2000). Methods in environmental analysis water, soil and air. Agrobios, 5: $1-400$.

Ibraheim, M.H. and Khater, Z. Z. K. (2013). The Effect of the electromagnetic field on water and fish Clarias garpienus, Zagazig, Egypt. Life Science Journal, 10(4): 3310-3324.

İncekara, Ü. (2009). Records of aquatic beetles (Helophoridae, Hydrophilidae, Hydrochidae, Dytiscidae) and physicochemical parameters in a Natural Lake (Artvin, Turkey). Tuk. J. Zool., 33: 89-92.

Khater, Z. Z. K. (2011). Ecological and biological studies on the effect of some water pollutants on some fishes. Ph. D. Thesis. Faculty of Science, Zagazig University, Egypt.

Khater, Z. Z. K. (2014). Yogurt and physicochemical parameters of water. Journal of American Science, 10 (9): 146-152.

Khater, Z. Z. K. and Ibrameim, M. H. (2015). Ecological studies on the effect of magnetic field on water. Int. J. Curr. Res. Aca. Rev., 3(8): 262-279.

Kholodov, Yu. A. (1974). Influence of magnetic fields on biological objects. American revolution bicentennial 1776- 1976, pp. 1-228.

Korai, A. L.; Sahato, G. A.; Lashari, K. H. and Arbani, S. N. (2008). Biodiversity in relation to physicochemical properties of Keenjhar Lake, Thatta District, Sindh, Pakistan. Turkish Journal of Fisheries and Aquatic Sciences, 8: 259-268.

Krzemieniewski, M. D.; bowski, M.; Janczukowicz, W. and Pesta, J. (2004). Effect of the constant magnetic field on the composition of dairy wastewater and domestic sewage. Polish J. Environ. Stud., 13: 45-53.

McCreadie, J. W.; Alder, P. H.; Grillet, M. E. and Hamada, N. (2006). Sampling and statistics in understanding distributions of black fly larvae (Diptera: Simuliidae). Acta Entomological Serbica, 11: 89-96.

Miclean, M. I.; Ştefãnescu, L. N.; Levei, E. A.; Şenilã, M.; Mãrginean, S. F.; Romam, C. M. and Cordoş, E. A. (2009). Ingestion induced health risk in surface waters near tailings ponds (North-Western Romania). AACL Bioflux, 2(3): 275-283.

Moon, J. D. and Chung, H. S. (2000). Acceleration of germination of tomato seed by applying an electric and magnetic field. J. Electro-Statistics, 48:103-114.

Owei, S. O. and Ologhadien, I. (2009). Environmental aspects of dredging intracoastal navigation channels in muddy coastlines: The case of Awoye, Ondo State, Nigeria. Journal of Food, Agriculture\& Environment, 7(2): 764-768.

Pandey, S. K. and Tiwari, S. (2009). Physico-chemical analysis of ground water of selected area of Ghazipur city-A case study.Nature and Science, 7(1): 17-20. 
Rahim, K. A. A.; Daud, S. K.; Siraj, S. S.; Arshad, A.; Esa, Y.; Ram, N. M.; Ulitzur, S. and Avnimelech,Y. (2009). Microbial and chemical changes occurring at the mud-water interference in an experimental fish ponds. Technion. Israel Institute of Technology, Haifa, publication No. 317.

Shatalov, V. (2009). Degassing as the mechanism of thermal electromagnetic fields effect on water and bioliquids. Donetsk, pp. 1-18.

Sithik, A. M. A.; Thirumaran, G.; Arumugam, R.; Kannan, R. R. R. and Anantharaman, P. (2009). Physico-chemical parameters of Holy Places Agnitheertham and Kothandaramar Temple; southeast coast of India. AmericanEurasian Journal of Scientific Research, 4(2): 108-116.

Sohaili, J.; Fadil, O. and Zularisham, A. (2004). Effect of magnetic fields on suspended particles in sewage. Malaysian J. Sci., 23: 141- 148.

Tai, C.Y.; Wu, C.K. and Chang, M. C. (2008). Effects of magnetic field on the crystallization of $\mathrm{CaCO} 3$ using permanent magnets. Chem. Engin. Sci., 63: 5606-5612.

Tsouris, C.; Depaoli, D.W.; Shor, J.T.; Hu, M.Z.C. and Ying, T.Y. (2001). Electrocoagulation for magnetic seeding of colloidal particles, Colloids Surf. Physicochem. Eng. Asp., 177: 223-233.

World Health Organization (WHO) (2008). Guidelines for drinking water quality. Geneva.

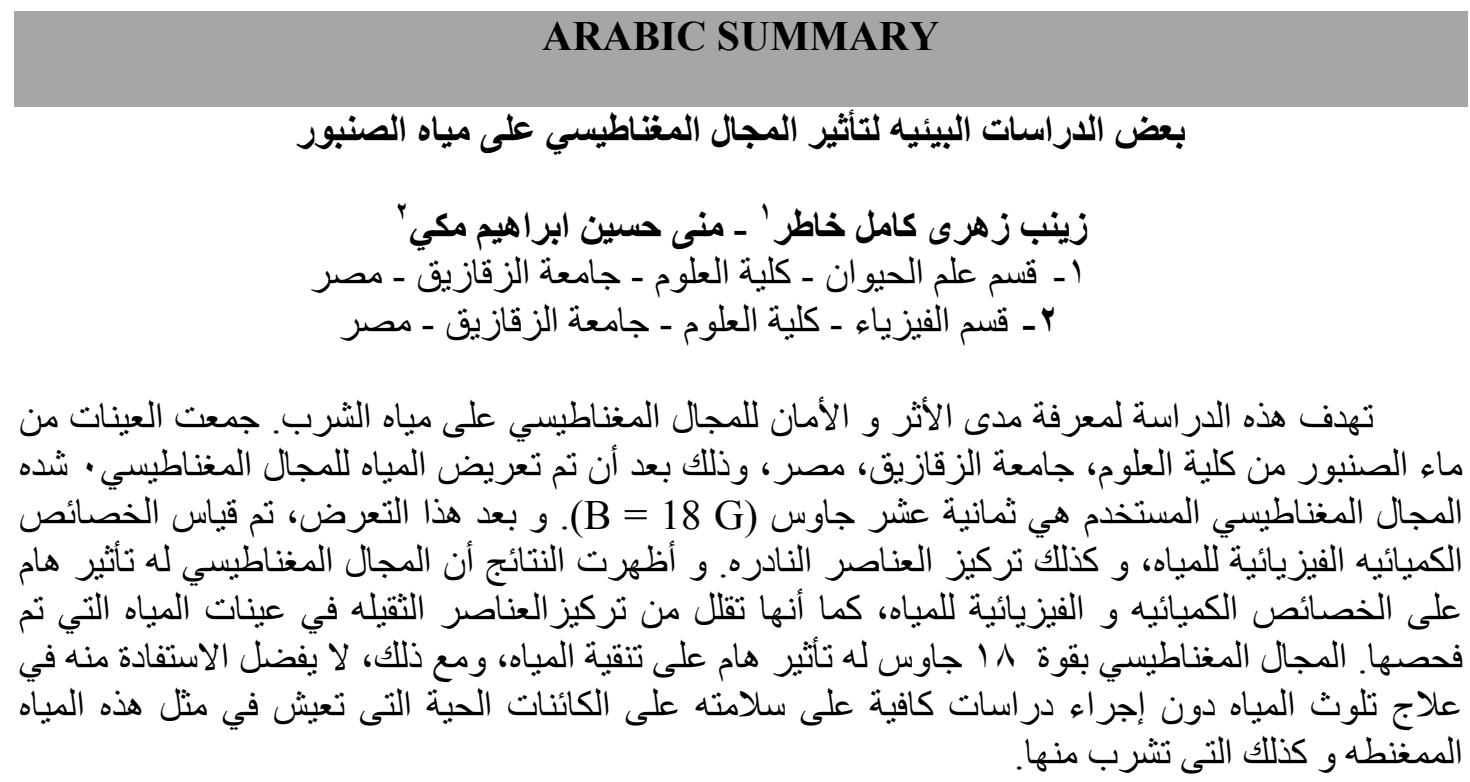

